\title{
Research Article \\ Exploring the Future of the Teaching Materials Center at Illinois State University: From e-Textbooks to Makerspaces
}

\author{
ANNE SHELLEY ${ }^{1}$ \\ Illinois State University, Normal, IL, USA \\ JULIA M. DERDEN ${ }^{2}$ \\ Illinois State University, Normal, IL, USA \\ SALLY GIBSON ${ }^{3}$ \\ Missouri Western State University, St. Joseph, MO
}

\begin{abstract}
In this project, co-investigators explored how college and university curriculum centers are addressing challenges with K-12 electronic textbooks (particularly acquisition, cataloging, and access) and implementing technology-focused services for pre-service teachers. The results of this research have provided guidance for planning the future of the curriculum center in Milner Library at Illinois State University, which comprises $2.5 \%$ of the library's holdings and accounts for almost $25 \%$ of the library's circulation. We identified service gaps and opportunities for improvement and are in the process of acting upon our findings, such as leveraging campus partnerships, integrating makerspace technologies, and exploring different models for ordering and processing the collection. ${ }^{4}$
\end{abstract}

Keywords: Textbooks, Academic library curriculum centers, Preservice teachers, Library materials, Library services

\footnotetext{
${ }^{1}$ Anne Shelley scholarly communication librarian and music librarian at Illinois State University. From 2012 to 2017, she was the multimedia librarian and helped support and promote media and technology use in Milner Library.

${ }^{2}$ Julia M. Derden is the Subject Liaison to the School of Teaching and Learning at Illinois State University and responsible for the large Teaching Materials Center (TMC) located in Milner Library. Her duties include handling a budget for all PK-12 material purchases and maintaining a current and relevant collection primarily used by preservice teachers across 28 education programs on campus.

${ }^{3}$ Sally Gibson is the library director at Missouri Western State University. From 2013 to 2016 she was the Head of Cataloging, Acquisitions, and Processing at Illinois State University. Her areas of responsibility included acquisitions, cataloging, electronic resources, and processing.

${ }^{4}$ This article is based on a research project funded by the University Research Grant program at Illinois State University. The authors presented a poster on this topic titled "Exploring the Future of the Teaching Materials Center at Illinois State University: From e-Textbooks to Makerspaces" at the 2017 American Library Association Annual Conference in Chicago, Illinois.
} 


\section{Introduction}

The Teaching Materials Center at Illinois State University's Milner Library is a collection of pre-K through grade 12 curriculum materials that support the University's pre-service teacher programs. It is a heavily used collection, as it comprises less than $3 \%$ of the library's holdings but accounts for over $25 \%$ of the library's circulation. While updating documentation related to collection development, cataloging and processing, instruction, and programming in the Teaching Materials Center, the Teaching Materials Librarian identified questions related to services that were not currently being offered in the Teaching Materials Center, but that might help prepare pre-service teachers for student teaching and their careers. Examples of these services are large format printing, Ellison die cuts, and circulating devices such as tablets, SMART technologies, and maker technologies.

A chief question of this research project was if and how other university curriculum centers were acquiring and providing access to electronic versions of textbooks, a source that pre-service teachers often consult for grade-level-appropriate lesson plans. In the past several years, updated print copies of textbooks have become difficult for university curriculum centers to purchase. Many school districts have moved toward a model of providing each student with a tablet or other electronic device, and students use the devices to access electronic copies of textbooks. Publishers have responded to this shift in format by only publishing certain titles in electronic format and applying a one-user/one-license model, therefore making it more challenging for university curriculum centers to purchase or license the most current textbooks available. As time goes on, the gap between the currency of curriculum center textbooks and those resources used in K-12 curricula will be providing a disservice to pre-service teachers.

There is currently no clear and reliable publishing model for K-12 e-textbooks, and there is little coverage of this topic in the library literature. Literature has focused on space design and integrating digital tools so that students are engaged in collaborative learning with an outcome of producing content rather than consuming information. Investigators chose to address this gap in the literature by performing site visits to peer and benchmark institutions to speak with other librarians about innovation in their curriculum centers. In addition, investigators contacted three major K-12 textbook publishers to explore what models they currently offer and to identify future trends.

The Teaching Materials Librarian invited two colleagues, the Head of Cataloging, Acquisitions, and Processing and the Multimedia Services Librarian, to study how other university curriculum centers were addressing the issue of electronic textbooks as well as other current practices and challenges involving curriculum centers. Investigators applied for and received internal funding through their college's University Research Grant program, which supported their travel to seven different libraries to view the curriculum centers, discuss issues with their counterparts, and collect data to consider for implementing changes at the Illinois State University Teaching Materials Center.

The project involved three prongs of exploration: identifying acquisitions, cataloging, and processing strategies for e-textbooks and other materials; managing the collection and its related services; and providing space, access, and support for technologies with which pre-service teachers need to become familiar before entering the field. Objectives and outcomes of the project were twofold: 1.) to explore and document if and how e-textbooks in curriculum centers are currently acquired, cataloged, and processed; and 2.) to perform a survey of successful 
integration of technology and innovative library spaces in academic curriculum centers, and how libraries are collaborating with stakeholders on their campuses.

\section{Literature Review}

Curriculum centers to support teacher education programs at institutions of higher education have existed in one form or another in the United States since the early twentieth century. Among the materials typically found in curriculum centers are picture books, fiction and non-fiction books, a professional development collection modeling one found in a school setting (with activity books, reference-type books, etc.), manipulatives, and most importantly, teacher edition textbooks covering all grades and disciplines. The importance of textbooks in the training of teachers appears early in the history of U.S. teacher education, from its apprenticeship roots in colonial times to the nineteenth-century view of textbooks as promoting mental discipline and rote learning (Kohrman, 2012, p. 7). Certainly, there were alternate models of teaching that were less reliant on textbooks and established curriculum, espoused by Johann Pestalozzi, Maria Montessori, and Horace Mann, among others.

In 1922, Western State Normal School (now Western Michigan University) began a curriculum bureau that was primarily for faculty use (Knauss, 1953). At about the same time, "curriculum laboratories" began to emerge as collocated materials spanning from curriculum guides, lesson plans, and teaching units to be used by teacher education students (Clark, 1982, $\mathrm{p}$. 1). The National Education Association adopted accreditation standards for four-year teacher colleges in Washington, D.C. in February of 1926, which included:

IX. Library, Laboratory, and Shop Equipment

A. Each teachers college shall have a live, well-distributed, and professionally administered library bearing specifically upon the subjects taught. At east [sic] fifteen thousand volumes, exclusive of public documents, are recommended as a minimum (NEA, 1926, p. 844).

By the 1930s, curriculum reform was front and center nationally, on the heels of curriculum planning that had previously occurred at the local school district level (Kliebard, 1986, p. 209).

Early curriculum centers, often referred to as [a] "Textbook Exhibit Library" housed at teacher preparation institutions included examples of elementary and secondary textbooks. These library collections included public school curriculum as represented in textbooks, teaching aids (charts, maps, ancillary equipment), and "[m]odel collections of books, suitable to various kinds of libraries, [and] the finer editions of children's literature.” (Rosenlof, 1929, p. 66) Some publishers of textbooks and children's books provided materials to these collections for teachers in training to examine, interact with, and use, reaching their intended audience far sooner than would have been possible by other means. Some materials came to these collections from teaching faculty who donated books to be used by a greater number of people through a centrally-administered library collection (Rosenlof, p. 67).

In an attempt to document the processes and procedures associated with these unique types of materials, Rosenlof sent surveys to 178 four-year teacher colleges and normal schools listed in the U.S. Bureau of Education's Educational Directory for 1926 and received responses from 115 institutions. Respondents provided data on their book and periodicals holdings, if the 
curriculum center was run by a department or the institution's library, if they offered a textbook exhibit library, and the library's staffing and budget. Based on the results of his study, Rosenlof provided recommended standards for academic curriculum centers (Rosenlof, p. 150). Following studies included those by Beatrice Leary in 1938 (Leary, 1938) ${ }^{5}$ and Frances Drag in 1947 (Drag, 1947). ${ }^{6}$ In 1979, the Educational and Behavior Sciences Section of the Association of College Research Libraries began surveying curriculum centers in the United States and Canada. Questionnaires were sent to accredited teacher education programs listed in the Directory of the American Association of Colleges of Teacher Education, and respondents represent departmental centers, library-run branches or collections, textbook adoption centers, and research collections. The first edition of the survey was published in 1981 and included information on 187 centers, while the seventh and most recent edition was published in 2015 and covers 161 centers, down significantly from 204 in 2009 (Gregor, et. al., 2015, p. 2).

Even with an emphasis on text-based items like textbooks and children's and young adult literature, the variety of formats and large volume of non-print items make curriculum center materials challenging to catalog and process. In their 2002 article, Loesch and Deyrup discuss cataloging decisions made when making a small curriculum collection visible in their online catalog, including recataloging items individually that were previously on one bibliographic record with multiple holdings, interfiling and shelving kits with print resources, and which classification system to use (Loesch and Deyrup, 2002, p. 80).

In these evolutionary and revolutionary times in preservice teacher education, the importance and value of curriculum centers is not in dispute, however their relevancy is largely dependent on their currency and relevancy to pedagogical approaches in the disciplines. Student and teacher edition textbooks provide a major touchstone to pre-kindergarten to Grade 12 preservice educators who are required in their coursework to write lesson plans mapped to learning standards and learning outcomes. Ball and Feiman-Nemser (1988) conducted a longitudinal study of two teacher education programs where students were encouraged to avoid textbooks in order to be an effective teacher. Their findings, however, indicated that textbook usage in clinical and student teaching placements was ubiquitous and that the preservice teachers were ill-equipped to critically evaluate the materials they encountered in the field. Additionally, the researchers found that many preservice teachers lacked the content knowledge to develop their own curriculum at this early stage in their teaching careers. Consequently, FeimanNemser's (1983) teacher as learner concept should be supported in additional to pedagogical approaches and critical appraisal of publisher-prepared materials. Zumwalt (1989) argues that an understanding of curriculum as inseparable from teaching allows teachers to make decisions during the curricular planning process and to square their beliefs with what they know to be sound educational practice. Lloyd and Behm (2005) found that elementary preservice teachers needed far more experience analyzing curriculum presented in mathematics textbooks in order to challenge their own preferences for the "familiar approach" when provided two pedagogical instructional methods to the same mathematical concept.

Standards-based instruction is dominating the $21^{\text {st }}$ century classroom, as is prescriptive curriculum. Preservice teachers should be exposed to prepared curriculum in their teacher education programs so that they will first know how to respond to questions in a job interview

\footnotetext{
${ }^{5}$ Leary's study included information on 35 centers.

${ }^{6}$ Drag reported on 145 academic curriculum centers, a significant increase from Leary's study.
} 
about their beliefs and experiences with such and secondly, to be able contribute to meaningful discussions about curriculum choices once working in a school setting. In curriculum centers, librarians often encounter preservice teachers, especially at the K-6 level, grappling with curricular content based on a standard and how to approach designing a lesson around a particular topic. How better to show an elementary education major what "science curriculum looks like in $4^{\text {th }}$ grade" than to open a teacher edition textbook in either the life, earth or physical science units? These same textbooks also provide education majors with something to "critique" as they learn about their disciplinary subjects.

\section{Concerns About E-textbooks}

With the shift toward e-textbooks/module-based content for K-12 students (Davis, 2013), librarians tasked with acquiring current and relevant textbook collections are finding it difficult to navigate the new terrain of e-textbooks, and particularly the one-user licensing model, which is of little to no use to a pre-service education program. While it is still possible to purchase print teacher edition textbooks from some publishers, many ancillary materials (e.g.: test samplers and additional resource material) are provided only on CD, DVD, or online with the one-user license access code/account (McGraw Hill, 2019). These access restrictions prevent pre-service teachers from seeing and utilizing the full range of materials available to them when crafting and designing lesson plans for their coursework. Librarians who serve these undergraduate education program faculty and students are concerned that future access to teacher edition textbooks (and student edition materials that might be critical to have in conjunction with the teacher materials) is on the decline, and user groups will be, if they are not already, negatively impacted.

Certainly, pre-service teachers become well-versed in objective/outcome development, lesson-planning, and assessment in their upper-class courses, but it is critical at this level of their coursework to have a "touchstone" when they are assigned a "second grade science lesson plan." Early childhood, elementary, and middle level majors are taught content and methods in all subjects, and secondary education majors are steeped in their discipline's content area, but still need the construct and structure of teacher edition materials to effectively navigate ageappropriate topics for a specific grade, crafting meaningful lessons and incorporating state, national, and/or Common Core standards into them.

While many school districts have opted to put Netbooks into their students' hands with downloaded content, this poses problems for university-based curriculum resource centers as pre-service teachers are exposed to a wide variety of materials in the course of their trainingfrom basal reading textbooks to activity books to inquiry-based manipulatives - and the Netbook model does not lend itself well to the collegiate environment with regard to K-12 teacher edition textbooks or accompanying student materials. For some preservice teachers, clinical placements may not be able to accommodate an added license for the student to use the teacher edition of the e-textbook outside of the classroom setting. This restriction hampers the clinical/preservice teacher in only being able to use time that their cooperating teacher has to stay at the school in order for them to be prepared for the coming days or weeks.

During our research site visits, the e-textbook problem was on the minds of many of the librarians who actively work with these collections. A member of one institution visited for this study even went so far as to state that "we are buying as many print teacher editions as possible before they quit publishing them." Not one of the curriculum centers in the study had been approached by a K-12 textbook representative regarding sales or purchase of e-textbooks. 
Digital content has unique issues from acquisition to cataloging to access phases. Curriculum centers are a special, niche market with specific needs and concerns, and most are eager to work with publishers to work through a way to get publishers' materials into the hands of pre-service teachers and education faculty. Post-site visits, the researchers began to actively contact sales representatives, beginning with the largest publishers. Describing the unique role of curriculum centers in teacher preparation and as future consumers of their materials was part of a deliberate strategy to interest sales representatives to see curriculum centers as having a big impact on teachers who would one day be participating in curricular decisions and purchasing in a school district. Framed in that way, curriculum centers are acknowledging that our purchasing dollars might not be as lucrative as they once were.

\section{Methodology}

Seven colleges and universities within driving distance of Normal, Illinois were identified as having teacher education programs supported by curriculum centers. An online survey was distributed to center representatives, followed by site visits to each location to collect data. ${ }^{7}$ In choosing which sites to visit, investigators decided to survey a variety of institution and curriculum center types, including one of each of the following: a small private college, a large public institution, a benchmark institution, ${ }^{8}$ a curriculum center within an academic library, and a decentralized curriculum center (housed in the academic department rather than the library). Because of the funding level available for the project, sites had to be within driving distance of central Illinois. Figure 1 shows basic information about each site visit location. ${ }^{9}$

\begin{tabular}{|c|c|c|c|}
\hline Center & Location & $\begin{array}{c}\text { Staffing } \\
\text { (Librarian }+ \text { Staff) }\end{array}$ & $\begin{array}{c}\text { School Profile } \\
\text { (UG=Undergraduate, } \\
\text { G=Graduate) }\end{array}$ \\
\hline A & Main Library & $1+3$ & Public, 21,000 UG+G \\
\hline B & Main Library & $<1+1-2$ & Private, 3,500 UG \\
\hline C & Main Library & $<1+3$ & Private, 2,000 UG +G \\
\hline D & $\begin{array}{c}\text { Main Library } \\
\text { (segmented) }\end{array}$ & $1+3$ & Public, 16,000 UG+G \\
\hline E & Branch Library & $1+2$ & Public, 25,000 UG $+\mathrm{G}$ \\
\hline F & Department Library & $2+2$ & Public, 21,000 UG+G \\
\hline G & Research Center & 3 & Public, 43,000 UG $+\mathrm{G}$ \\
\hline
\end{tabular}

Figure 1, Site Visit Profiles ${ }^{10}$

A separate online survey was distributed through vendor representatives to three, large K-12 textbook publishers. Investigators received no responses to this survey. ${ }^{11}$

\footnotetext{
${ }^{7}$ Questions asked in the pre-site-visit survey are listed in Appendix A.

${ }^{8}$ Illinois State University has identified eight peer universities in the United States as benchmark institutions.

${ }^{9}$ Questions asked during the site visit are included in Appendix B.

${ }^{10}$ Consult this chart for institution designations later in the paper.

${ }^{11}$ Questions asked in the textbook publisher survey are listed in Appendix C.
} 


\section{Results}

\section{Acquisitions}

Purchasing K-12 textbooks is a major challenge, as publishers are producing more online, supplemental materials to accompany the Teacher Edition textbook, and the one-user/one-license model is not suited for curriculum centers. Curriculum centers surveyed are not actively purchasing electronic "regular" books, as the FTE pricing model makes affordability a major obstacle. Housing of unusual materials was discussed. A significant takeaway of the site visit interviews was that packaging decisions are best made before cataloging (e.g.: bags for puppets).

Services and collections provided at Institution E are split between two locations: K-12 educational resources, services, and machine/manipulatives are part of a branch curriculum library and print resources such as textbooks and lesson planning books located in another library. In the few years prior to this interview, this institution made an effort to purchase as many print textbooks as possible. Manipulatives such as puppets and educational kits are a popular service at this curriculum center.

While Institution B once relied on gratis copies from publishers to complete their textbook collection, these copies are generally no longer offered, and the institution has not been actively purchasing textbooks due to challenges previously mentioned. The library has involved interested teacher education faculty in collection management projects, such as withdrawing resources that are no longer used or relevant to the curriculum. While the curriculum center in this library is somewhat traditional, offering small tables for individual and group work, a circulating collection of children's books and educational kits, it is directly adjacent to a multimedia technology lab and service point. The technology-rich space and services are available to all patrons on campus, but it is most heavily used by students enrolled in education courses.

Institution $\mathrm{C}$ has had difficulty acquiring current print textbooks from publishers. They have been relying on donations of spare sets from local school districts. As of early 2016, their most recent textbook edition was dated 2008-9. Institution D noted that their textbooks are heavily used for lesson planning, so they are kept in a ready reference section. The same institution allows most other materials in their curriculum center to circulate through interlibrary loan. Institution $\mathrm{G}$ is a reference collection located at a large research university. The majority of the collection is comprised of review copies donated by publishers. In addition to employing four staff members at a combined 3.0 FTE, the center also has seven graduate assistants who work at the reference desk and catalog materials.

Institution $\mathrm{F}$ does not circulate their print textbook collection outside the library. The library has partnered with academic departments on campus for financial support to purchase textbooks, but the demand for new or more textbooks has been minimal.

\section{Technical Services}

Often staff are responsible for cataloging materials in the curriculum centers in addition to other areas of responsibility. There is interest in having cataloging staff dedicated to the curriculum centers, but there is also a lack of funding for positions. Dewey classification and local cataloging practices create complications. Items are often unique and require original 
cataloging. Insufficient staffing can cause items to remain uncatalogued and unavailable. All curriculum centers discussed the need to have a strong working relationship with the catalogers at their institutions.

At Institution A, cataloging of materials is handled by two professional catalogers and three copy catalogers. Responsibilities are divided by format and a variety of classification schemes are used. Non-book materials are assigned accession numbers and held in a closed stack area. Challenges include cataloging a large backlog of 2D and 3D objects, and kits. Materials are unique and require original cataloging and determining how to organize and store the materials can be problematic. Changes to state textbook adoption have negatively impacted local cataloging practices.

Institution B does not have a dedicated cataloger and the material is cataloged in house. The material is classed by Library of Congress. Institution $\mathrm{C}$ would like to reclassify the collection into Dewey Decimal but lacks sufficient staffing levels and time to accomplish such a project. Institution D has less than 20 hours per week dedicated to cataloging materials in the curriculum center. Institution $\mathrm{E}$ has kits and materials that need to be packaged before cataloging. How the materials are packaged can assist with the overall check-out process and how easy it is to use the item outside of the library. One challenge is that the curriculum center is physically separated from the main library. It can be difficult to discuss the cataloging needs of the collection since those working with the collection do not always interact with those cataloging the collection.

\section{Technology and Media}

Technology and related services offered varied greatly among site visit locations. One institution provided only desktop computers, while another circulated tablets, camcorders, etc. and had a technology-rich, flexible classroom equipped with SMART and Promethean software. Several sites offered lamination, binding, Ellison die cuts and machines, large-format printing, scanning, and software, equipment, and staff support for video editing projects. Providing a variety of educational technologies to preservice teachers is important to prepare them for a school setting, whether needed for coursework or for additional practice.

Institution A offers several multimedia editing computers, which happen to be near the curriculum collection and a service point at which students can borrow a variety of circulating technologies. Both this institution and Institution $\mathrm{C}$ would have liked to offer Ellison die cuts in the library, but those sets were retained or reclaimed by the teacher education department/college.

Institution B offers a staffed multimedia center and circulating technology service point directly adjacent to the curriculum collection. In designing the technology lab, the library worked with a team of engaged and knowledgeable students, and they also surveyed principals and technology specialists at different school districts in the state to determine what technologies are currently being used by practicing teachers. A full-time staff person oversees the technology lab, and the lab also employs several student workers who investigate emerging technologies and provide training for patrons. Some of the popular services at both the curriculum center and the technology lab include binding, Ellison die cuts, and large format poster printing.

While not located in the curriculum center, Institution D offers a technology-focused area for students. Services and technology offered in this space include audio and video editing 
workstations, 3D printers, and a small room set up as a video studio. At the time, staff were considering offering the Oculus Rift virtual reality system.

While Institution $\mathrm{E}$ does not have a dedicated makerspace in their curriculum library, they provide a variety of fee-based maker services and consumable products, many of which are popular with students. Consumables include construction paper, card stock, poster board, and Velcro tape, and other services and technology include lamination, spiral binding, a button maker, and poster printing. Lamination, binding, and Ellison die cuts are especially popular with patrons at this curriculum center.

Institution $\mathrm{F}$ does not have a formal makerspace but does have a room dedicated to technologies such as Ellison die cuts, book binding, poster printing, lamination, and photocopying. This curriculum center circulates digital cameras, camcorders, laptops, Chromebooks, and iPads, and provides other technologies in the library such as collaboration tables with monitors and a SMART board with an interactive projector.

Institution $\mathrm{G}$ offers some programming that integrates technology. For example, the center collaborates with a local teacher to offer a grant-funded, two-week-long film camp in which middle-level students with below average reading ability use iPads to create video trailers for young adult novels. This institution is interested in expanding its technology use; staff plan to acquire iPads through grant funds so patrons can use the devices to view book review sites like NetGalley. $^{12}$

\section{Discussion}

Data collected at the site visits revealed that textbook collections are increasingly difficult for academic curriculum centers to build and maintain. Print edition textbooks typically are no longer available for free from publishers, and no sites visited are actively collecting e-textbooks. Curriculum center librarians realize changes are needed but are generally uncertain of the next steps. Discontinued state-adopted textbook programs contribute to the challenge.

The most revealing aspect of this study is probably also its most notable limitation: because academic curriculum centers are essentially unable to collect e-textbooks, we were unable to capture much data about how these resources are acquired, processed, and distributed to users.

Shortly after we concluded the site visits for this research project, a working group began a separate initiative to investigate installing a makerspace in our library. Some of the tools and services discussed by the makerspace working group overlapped naturally with what we discovered during the site visits, such as a button maker, comb binder, laminator, and Ellison die-cuts. Space and furniture have been identified in the library to offer these new tools, and they will be available for the university community and public patrons to use starting in Fall 2018. These services, in particular, are important for our library to provide, as we are filling a service gap left by a popular vendor who recently vacated their space in our student union (which is adjacent to the library).

Although investigator attempts to engage large textbook publishers in this issue have so far been unsuccessful, we have recently connected with several small companies who are willing to discuss ways to make K-12 textbooks electronically available to university curriculum centers.

${ }^{12}$ See NetGalley, https://www.netgalley.com/ (accessed August 1, 2018). 


\section{Conclusion}

More research is needed on how curriculum centers in academic libraries can help publishers understand our unique role in providing preservice teachers access to e-textbooks, which are currently largely unavailable to them based on their publishing model. Additional research is needed on the possibility of outsourcing cataloging of curriculum materials to a vendor. Our library will soon offer several services, such as Ellison die cuts and button making, that should benefit pre-service teachers; we feel confident these services will be used in part due to the data we collected during this project. We are having early discussions with smaller publishers and vendors who supply e-textbooks. We are working to increase their awareness of the unique needs of academic curriculum centers and hope to successfully advocate for alternative publishing models.

\section{References}

Anderson, B., \& Curriculum Materials Centers Directory Revision Ad Hoc Committee of the Education and Behavioral Sciences Section. (Eds.). (1996). Directory of curriculum materials centers $\left(4^{\text {th }}\right.$ ed.). Chicago, IL: Association of College and Research Libraries.

Ball, D., \& Feiman-Nemser, S. (1988). Using textbooks and teachers' guides: A dilemma for beginning teachers and teacher educators. Curriculum Inquiry, 18(4), 401-423. doi: $10.2307 / 1179386$

Carr, J. A. (Ed.). (2001). A guide to the management of curriculum materials centers for the $21^{\text {st }}$ Century: the promise and the challenge. Chicago, IL: Association of College and Research Libraries, American Library Association.

Catalano, A. (2015). Collecting for the curriculum: the common core and beyond. Santa Barbara, CA: Libraries Unlimited.

Clark, A. S. (1982). Managing curriculum materials in the academic library. Metuchen, NJ: Scarecrow Press.

Curriculum Materials Centers Directory Ad Hoc Committee of the Education and Behavioral Sciences Section. (2009). Directory of curriculum materials centers $\left(6^{\text {th }}\right.$ ed.). Chicago, IL: Association of College and Research Libraries.

Davis, M. R. (February 6, 2013). 'Big three' publishers rethink K-12 strategies. Education Week: Digital Directions. Retrieved from https://www.edweek.org/dd/articles/2013/02/06/02textbooks.h06.html.

Drag, F. (1947). Curriculum laboratories in the United States. Education Monograph, No. 15. San Diego: Curriculum Laboratory, Office of the Superintendent of Schools, San Diego County.

Gelber, N. (2013). Managing a curriculum materials collection: One academic library experience. Collection Management, 38(1), 51-66. https://doi.org/10.1080/01462679.2012.731033 
Education Libraries, 41(2018)

(C)Education Division, Special Library Association

Gregor, M., Kohrman, R., Lueck, L., Teel, L., \& Walker, J. (2015). Directory of curriculum material centers and collections ( $7^{\text {th }}$ ed.). Chicago, IL: Association of College and Research Libraries.

Kliebard, H. M. (1986). The struggle for the American curriculum, 1893-1958. Boston: Routledge \& Kegan Paul.

Knauss, J. O. (1953). The first fifty years: A history of Western Michigan College of Education, 1903-1953. Kalamazoo, MI: Western Michigan College of Education.

Kohrman, R. (2015). Current condition of Michigan curriculum materials centers and collections in academic institutions. Education Libraries, 38(1), 8-15.

Lare, G. A. (2004). Acquiring and organizing curriculum materials: A guide and directory of resources. Lanham, MD: Scarecrow Press.

Leary, B. L. (1938). Curriculum laboratories and divisions: Their organization and function in state departments of education, bulletin 1938, no. 7. Washington, DC: Government Printing Office.

Lehman, L. J., \& Kiewitt, E. L. (Eds.). (1985). Directory of curriculum materials centers (2 ${ }^{\text {nd }}$ ed.). Chicago, IL: Association of College and Research Libraries.

Lloyd, G. M., \& Behm, S. L. (2005). Preservice elementary teachers' analysis of mathematics instructional materials. Action in Teacher Education, 26(4), 48-62.

Loesch, M. F., \& Deyrup, M. M.. (2002). Cataloging the curriculum library: New procedures for non-traditional formats. Cataloging \& Classification Quarterly, 34(4), 79-89. https://doi.org/10.1300/J104v34n04_08

McGraw Hill Education. (2019). 2019 Mathematics 6-12 Catalog. Retrieved from https://s3.amazonaws.com/ecommerceprod.mheducation.com/unitas/school/catalogs/2019/2019-mathematics-catalog.pdf.

Miller, J., \& Meyer, N. (2008). Transforming a curriculum center for the $21^{\text {st }}$ century at Eastern Washington University Libraries. Education Libraries, 31(2), 19-30.

Mirtz, R. (2010). From information to learning: Pedagogies of space and the notion of the commons. College \& Undergraduate Libraries, 17, 248-259. https://doi.org/10.1080/10691316.2010.487446

National Education Association of the United States. (June 27-July 2, 1926). Proceedings of the sixty-fourth annual meeting. Philadelphia, Pennsylvania.

Osier, D. V., Wright, C., Lawrence, J., Collins, M. E., \& Anderson, B. (1990). Directory of curriculum materials centers ( $3^{\text {rd }}$ ed.). Chicago, IL: Association of College and Research Libraries.

Rosenlof, G. W. (1929). Library facilities of teacher-training institutions. New York: Teachers College Press.

Sullivan, R. M. (2010). Common knowledge: learning spaces in academic libraries. College \& Undergraduate Libraries, 17, 130-148. https://doi.org/10.1080/10691316.2010.481608

Zumwalt, K. (1989). Beginning professional teachers: The need for a curricular vision of teaching. In M.C. Reynolds (Ed.) Knowledge base for the beginning teacher (pp. 173184). Elmsford, NY: Pergamon Press. 


\section{Appendix A - Pre-Site Visit Survey Questions}

1. What is the name of your institution's curriculum center?

2. Where is your institution's curriculum center located?
a. Main library
b. Satellite library
c. Part of College or School of Education
d. Other (please specify)

3. How many years has your institution had a curriculum center?
a. $0-10$
b. $11-20$
c. 21-30
d. $31+$

4. What are the hours of the curriculum center?

a. [indicate hours open each day of the week]

5. Is there a dedicated librarian for the curriculum center?
a. Yes
b. No. If not, please indicate other responsibilities with curriculum center duties.
c. Other (please specify)

6. How many dedicated staff members support your curriculum center (do not include yourself in this total)?
a. Less than 1 FTE
b. 1-2 FTE
c. 3+FTE
d. Other (please specify; please provide details)

7. Is your institution a state depository and/or review center for textbooks?
a. Yes
b. No

8. Which of the following services does your institution provide (whether in the curriculum center, library, both, other, none)?
a. Lamination
b. Die cuts
c. Materials for "make and take" (e.g. poster board, colored paper, etc.)
d. Workshops for "make and take"
e. E-textbooks
f. E-books (please specify picture books, novels, etc. in the textbox below)

9. Does the curriculum center have a separate collection development policy?
a. Yes
b. No

10. Does the curriculum center have its own challenged book policy/procedure(s)?
a. Yes
b. No

11. How many cataloging staff support the curriculum center?

a. We do not have a dedicated cataloger/staff for the curriculum center.

b. Less than 1 FTE 

c. 1-2 FTE
d. 3+ FTE

12. Is the curriculum material cataloged in-house or outsourced?
a. In house
b. Outsources
c. Other (please specify)

13. Is the curriculum center collection divided into sub-collections? Please check all that apply.
a. Print books
b. Kits, games, manipulatives
c. Textbooks (student and/or teacher editions)
d. Multimedia
e. Other (please specify)

14. How is the curriculum material classed?
a. Library of Congress (LOC)
b. Dewey Decimal (DDC)
c. Combination of LOC and DDC
d. Other (please specify)

15. How are teacher edition e-textbooks available?
a. We do not provide e-textbooks
b. Single device
c. Web-based
d. Single user log in
e. Multi-user access
f. Other (please specify)

16. Have you made any changes to acquisition, cataloging or processing policies and/or practices within the past two calendar years? If yes, please explain.
a. Yes (provide details below)
b. No
c. Details, if Yes

17. How does your curriculum center's mobile devices (laptops, tablets, etc.) circulate?
a. Through ILS circulation
b. Manual checkout
c. We do not provide mobile devices
d. Other/details

18. What is your experience with technological challenges/restrictions (e.g. digital rights management, single license only availability for e-textbooks, etc.) involved with etextbooks/technology, if any (if none, please answer n/a)?

19. Please indicate which services are offered at either the curriculum center and/or library. Check all that apply.
a. Computers
b. Handheld devices (iPads, other tablets, etc.)
c. Specialty software (e.g. multimedia production)

20. Please indicate the curriculum center's most recent FY budget amount(s) below:
a. Collection budget amount
b. Technology budget amount 
Education Libraries, 41(2018)

CEducation Division, Special Library Association

c. Other budget amount

21. What is the FTE (enrollment) of your institution?

a. 1-2,000 FTE

b. 2,001-5,000 FTE

c. 5,001-10,000 FTE

d. 10,001-15,000 FTE

e. 15,001-20,000 FTE

f. In excess of 20,001 FTE

g. Please provide the number or percentage of education majors (if known) below 


\section{Appendix B - Site Visit Questions}

1. Tell us about curriculum center.

2. Tell us about your textbook acquisition and circulation processes.

3. Tell us about your vendor relationships/approval plans.

4. Tell us about your makerspace or plans for building a makerspace.

5. Tell us about your most popular services.

6. Tell us about your least successful services/ideas.

7. Are you willing to share any relevant documentation with us?

8. Tell us about your staffing.

9. Tell us about any cataloging challenges or local practices.

10. Tell us about any emerging technologies you've implemented to support your curriculum center.

11. What are some of the biggest challenges you face?

12. What would you like to do in the next three years? 


\section{Appendix C - Textbook Publisher Survey Questions}

1. Please indicate the name of your publishing company.

2. Do you make special accommodations for academic library acquisitions of teacher education textbooks? If yes, please indicate what accommodations you make in comments.
a. Yes
b. No
c. Don't know
d. Comments

3. Do you currently provide a purchasing and use model for institutions that support teacher education?
a. Yes
b. No
c. Don't know

4. Please indicate which of the following is available to academic institutions with curriculum centers that serve education majors (check all that apply).
a. Print student edition textbooks
b. Print teacher edition textbooks
c. E-textbook for student edition
d. E-textbook for teacher edition
e. Don't know
f. If you checked print student or print teacher edition textbooks above, please indicate the number of years you intend to continue doing so

5. Please indicate which of the following PK-12 textbooks your firm (and its imprints) publishes. (Note: If your firm publishes K-6, please check the PK-6 option).
a. PK-6 Reading
b. PK-6 Language Arts
c. PK-6 Math
d. PK-6 Social Studies
e. PK-6 Science
f. Middle level/Jr. High Reading/Literature
g. Middle level/Jr. High English
h. Middle level/Jr. High Math
i. Middle level/Jr. High Social Studies/History/Geography
j. Middle level/Jr. High Science
k. Secondary (High School) Literature
1. Secondary (High School) English
m. Secondary (High School) Math
n. Secondary (High School) Social Studies/History/Geography
o. Secondary (High School) Science
p. Other (please specify)

6. If you sell e-textbooks to academic institutions with curriculum centers that support preservice teacher education, please indicate which of the following options are applicable (check all that apply). 

a. One user-one license
b. Unlimited use of e-textbook
c. Flat rate pricing on e-textbooks, negotiated with the institution
d. Pricing based on institution's FTE
e. Pricing based on institution's pre-service teacher education FTE
f. Recurring licensing cost
g. Don't know
h. We do not sell e-textbooks to academic institutions

7. If you sell e-textbooks to academic institutions with teacher education programs/curriculum centers, please indicate the following hardware/software/platform options (check all that apply).

a. We provide recommended hardware requirements for our e-textbooks

b. We provide recommended browser requirements to be used with our e-textbooks

c. Our e-textbooks are available through an app

d. Our e-textbooks are available for use on one device

e. Our e-textbooks are available for use on multiple devices

8. Please indicate any additional information that might benefit the research we are doing on etextbooks and academic institutions with curriculum centers. 
Education Libraries, 41(2018)

CEducation Division, Special Library Association

\section{Appendix D - Informed Consent Form}

Informed Consent to Participate in Research: Participant

Information to consider before taking part in research that has no more than minimal risk.

Title of Research Study: Exploration of the Materials, Services, and Administration in a $21^{\text {st }}$ Century Teaching Materials Center (TMC)

We are librarians at Milner Library, Illinois State University. We are conducting research on planning the future of the Teaching Materials Center in Milner Library, Illinois State University. We are studying how other curriculum centers are preparing pre-service teachers for the field. Specifically, we will be asking participants general questions about how they are navigating the challenges of K-12 e-textbooks, acquisitions and cataloging of these materials, as well as technology-related services to support pre-service teachers. Institutional consent has already been obtained; please see attached document.

\section{What will I be asked to do?}

We would like to visit with librarians and library staff who work with the curriculum center materials, specifically the acquisition, cataloging, management, and delivery of K-12 teacher edition physical and/or e-textbooks. Photographs of facilities, collections, technology will be taken for the purposes of capturing operations of the curriculum center, and will be used according to the wishes of the institution. The people who choose to participate in this research will be asked to do the following:

\section{1) Initial Institutional Informed Consent}

- This document must be reviewed, approved, and returned by an institutional representative prior to the researchers contacting participants at your institution.

- This step has already been completed.

2) Initial E-mail Survey

- Sign informed consent (via an online survey)

- Complete survey (online) - approximately 15-20 minutes

3) Site Visit to Institution

- Meet for no longer than one business day at a mutually agreed upon time, prior to June 2016

- Respond to site visit questions

Here are the following instruments and questionnaires we will be using and why they are being used.

\begin{tabular}{|l|l|}
\hline Instruments & \multicolumn{1}{c|}{ Purpose } \\
\hline Informed Consent from Institution & Obtain voluntary consent \\
\hline Informed Consent from Individual(s) & Obtain voluntary consent \\
\hline Survey (online) & $\begin{array}{l}\text { Obtain baseline information on curriculum } \\
\text { center }\end{array}$ \\
\hline
\end{tabular}


Education Libraries, 41(2018)

CEducation Division, Special Library Association

\begin{tabular}{|c|l|}
\hline Site visit & $\begin{array}{l}\text { Obtain more detailed information about } \\
\text { curriculum center }\end{array}$ \\
\hline Questionnaires & Duration \\
\hline Survey (online) & $15-20$ minutes \\
\hline Site visit & Not to exceed one business day \\
\hline
\end{tabular}

Why is this research being done?

Institutions that have pre-service teacher education programs tend to have curriculum centers comprised of materials that support that demographic. The most unique and critical items in curriculum center collections is student and teacher edition textbooks - their organization, availability, and access to them. By all indications, the industry shift is towards publishing these materials in electronic format. The purpose of this research is to visit with librarians at institutions similar to ours who are experiencing concerns and challenges in terms of acquisitions, management, and access. By doing this research, we hope to learn about the concerns and best practices regarding challenges of K-12 e-textbooks in peer institution curriculum centers.

\section{Why am I being invited to take part in this research?}

You are being invited to take part in this research because it has a curriculum center.

Participation is voluntary. If your institution takes part in this research, it will be one of about 7 institutions to do so.

\section{Are there reasons I should not take part in this research?}

The risks associated with this research and your participation are no more than what you would experience in real life. As a benefit, your participation will contribute to the literature on the changing climate of curriculum material centers and how best to deal with the shift in the publishing industry regarding their model of publication of student and teacher edition textbooks and distribution issues that impact curriculum centers. If you do decide to participate, you may withdraw from participation at any time, but in doing so, the inclusion of your institution as part of our survey and site visits will cease.

There is a slight chance of the loss of confidentiality as results of this research may be published in an article or presented at a conference. While every attempt will be made to generalize our findings, it may be necessary to identify institutions and there is a slight risk of you being associated with your institution. There is a very slight possibility for loss of employability.

\section{What other choices do I have if I do not take part in this research?}

You can choose not to participate.

Where is the research going to take place and how long will it last?

The site visit will take place at a mutually agreed upon date and time and the length of the visit shall not exceed one business day.

What possible harms or discomforts might a participant experience by taking part in the research? 
The risks associated with this research are no more than what a person would experience in real life. Complete confidentiality cannot be guaranteed. Only researchers will be aware of privately identifiable information.

What are the possible benefits I might experience from taking part in this research? By participating in this research study, participants will contribute to better understanding by librarians of emerging publishing models with K-12 teacher edition e-textbooks and management of those materials. The results of this study may give agency to the collective of curriculum center staff in approaching textbook publishers about the needs of this niche, yet important, constituent group.

\section{What will it cost me to take part in this research?}

It will not cost you any money to be part of the research. The sponsor of this research will pay the costs associated with the study, such as travel and salary. However, we will be meeting with individuals during working hours, hence some of your university-paid time will be taken up.

\section{How will confidentiality be maintained?}

The information obtained in this research will be treated as confidential and will not be released to any person without the institution's or individual's expressed written consent. The researchers will keep the participants' responses confidential. However, complete confidentiality cannot be guaranteed since other participants may know that your institution is participating and may mention conversations they experienced during the site visits with others outside the study. The data will be presented in aggregate. No individual names or data will be used. Carnegie Classifications will be used in research presentations or publications to discuss research findings at different institutions. No one other than the research team will have access to your institution's data, including online survey responses and information gathered during the site visit. Finally, remember that it is no individual person's or institution's data that interest us; we are studying awareness of the research problem and potential development of best practices.

How will you keep the information you collect from me secure? How long will you keep it? Information collected will be kept for 5 years. The electronic data will be kept on a password protected computer and hard copies of data will be kept in a locked filing cabinet in the primary investigator's locked office. All data will be kept secured, in accord with the standards of the University and federal regulations.

\section{What if I decide I do not want to continue in this research?}

You may discontinue participation at any time. If you decide you no longer want to be in this research after it has already started, you may stop without penalty of loss of benefits.

\section{Whom should I contact with any questions?}

If you have questions about your rights as someone taking part in research, you may contact the Research, Ethics, and Compliance Office at 309-438-2529 and/or rec@ilstu.edu.

\section{I would like to grant permission to take part in this research. What should I do now?}


The person obtaining informed consent asks you to read the following. If you agree, you should sign this form:

- I have read (or had read to me) all of the above information.

- I am at least 18 years of age.

- I have had an opportunity to ask questions about things in this research I did not understand and have received satisfactory answers.

- I know that our institution can stop taking part in this study at any time.

- By signing this informed consent form, I am not giving up any of my rights.

- I have been given a copy of this consent document, and it is mine to keep.

- After providing written consent by signing below, please scan the entire form and e-mail the file as a PDF attachment to the principal investigator

Participant Name (PRINT)

Signature

Date

\section{Participant Institution (PRINT)}

\section{Participant Department (PRINT)}

